\title{
ANALISIS PENGARUH SUHU DAN KEMASAN PADA PERLAKUAN PENYIMPANAN TERHADAP KUALITAS MUTU FISIK CABAI MERAH KERITING (CAPSICUM ANNUM L.)
}

\section{Effect of Temperature and Packaging on Physical Quality of Curly Red Chili (Capsicum annum L.) During Storage}

\author{
Yolanda Reptami Putri, Nafis Khuriyati*, Anggoro Cahyo Sukartiko \\ Departemen Teknologi Industri Pertanian - Fakultas Teknologi Pertanian -Universitas \\ Gadjah Mada \\ Jl. Flora nomor 1 Bulaksumur - Yogyakarta 55281 Indonesia \\ *Penulis Korespondensi, email : nafis.khuriyati@ugm.ac.id
}

Disubmit: 30 September 2019 Direvisi: 22 April 2020 Diterima: 4 Juni 2020

\begin{abstract}
ABSTRAK
Cabai merah keriting (Capsicum annum L.) merupakan produk hortikultura bernilai ekonomi dengan permintaan yang tinggi baik di pasar dalam maupun luar negeri. Cabai tergolong sebagai produk klimaterik yang mudah rusak, membuat produk ini rentan mengalami penurunan mutu. Untuk itu diperlukan upaya penjagaan mutu cabai. Penelitian bertujuan untuk mengetahui kombinasi terbaik dari masing-masing faktor perlakuan selama penyimpanan. Penelitian ini dilakukan menggunakan rancangan eksperimen Taguchi, yang disusun berdasarkan matriks orthogonal $\mathrm{L}_{9}\left(4^{3}\right)$. Pada penelitian ini terdapat empat faktor kendali yang masing-masing terdiri dari 3 level, yaitu faktor suhu $\left(5^{\circ} \mathrm{C}, 10^{\circ} \mathrm{C}, 24^{\circ} \mathrm{C}\right)$, jenis kemasan (OPP, LDPE, PET), waktu simpan (2, 4, dan 6 hari), dan bulk density $(0,156 \mathrm{~g} / \mathrm{cc}, 0,243 \mathrm{~g} / \mathrm{cc}$, dan 0,313 g/cc). Dilakukan pengujian terhadap empat parameter mutu cabai merah keriting, yaitu tingkat kerusakan, perubahan warna, perubahan bobot, dan tingkat kekerasan dengan karakteristik semakin kecil nilai semakin baik. Analisa data dilakukan dengan menggunakan rasio signal gangguan (signal to noise ratio), efek faktor, dan analisis variansi. Dari penelitian ini diperoleh kombinasi terbaik level faktor yaitu suhu $5{ }^{\circ} \mathrm{C}$, jenis kemasan oriented polystyrene (OPP), waktu simpan dua hari, dan bulk density 0,243 $\mathrm{g} / \mathrm{cc}$. Pada kondisi tersebut persentase kerusakan $0 \%$, perubahan bobot $0,01 \mathrm{~g}$, perubahan warna senilai 5,54, dan perubahan kekerasan 0,74 gf. Sehingga pengaruh suhu dan kemasan pada perlakuan penyimpanan ini tidak berpengaruh signifikan atau berpengaruh signifikan.
\end{abstract}

Kata Kunci: Cabai Merah Keriting; Mutu Cabai; Taguchi

\begin{abstract}
Curly red chili (Capsicum annum L.) is a horticultural product that has an economic value with high demand in both domestic and foreign markets. Chili is classified as a climacteric product that is easily damaged, making this product vulnerable to deterioration. For this reason, efforts are required to maintain the quality of the product. The research aims to find out the best combination of each treatment factor during storage. This research was conducted using the Taguchi experimental design, which was arranged based on the orthogonal matrix $L_{9}\left(4^{3}\right)$. In this study, there were four selected factors, each of which consisted of 3 levels, i.e., temperature $\left(5^{\circ} \mathrm{C}, 10^{\circ} \mathrm{C}\right.$, and $\left.24^{\circ} \mathrm{C}\right)$, type of packaging (OPP, LDPE, PET), storage time $(2,4$, and 6 days), and bulk density $(0.156 \mathrm{~g} / \mathrm{cc}, 0.243 \mathrm{~g} / \mathrm{cc}$ and $0.313 \mathrm{~g} / \mathrm{cc})$. Four selected quality parameters of red curly red chili, i.e., the level of damage, color changes, weight changes, and the level of hardness, were tested with the characteristics the smaller the better. Signal to noise ratio, factor effects, and variance analysis was then performed on the collected experimental data. The conclusion of this study indicated the best combination of factor levels was: $5{ }^{\circ} \mathrm{C}$, oriented polystyrene (OPP) packaging, two-days storage time,
\end{abstract}


and bulk density of $0.243 \mathrm{~g} / \mathrm{cc}$. Under these conditions, the percentage of damage was $0 \%$, weight change of $0.01 \mathrm{~g}$, change in color valued at 5.54 , and change in hardness of $0.74 \mathrm{gf}$.

Keywords : Curly Red Chili; Quality; Taguchi

\section{PENDAHULUAN}

Cabai merah merupakan produk hortikultura yang memiliki permintaan yang tinggi baik dipasar dalam negeri maupun luar negeri. Rata-rata tingkat konsumsi cabai merah per kapita mencapai $1,4 \mathrm{~kg}$ per tahun pada tahun 2015 dengan kisaran harga cabai Rp 30.000-, sampai Rp 40.000-,. Dengan proyeksi jumlah penduduk Indonesia yang tahun 2019 sebanyak 265.015 ribu jiwa, berarti Indonesia membutuhkan cabai sebesar $\pm 1,070$ juta ton per tahun (Kementerian Pertanian, 2018). Cabai merupakan produk yang mudah rusak (perishable). Hal ini disebabkan proses respirasi yang masih terus berlangsung setelah dipanen. Cabai tergolong sebagai produk pertanian klimaterik (David dan Kilmanun, 2016).

Jika produk cabai tidak ditangani dengan baik setelah panen, maka mutu cabai akan mengalami penurunan seperti pembusukan yang ditandai dengan tekstur cabai yang sudah layu serta warna cabai yang sudah berubah menjadi kecoklatan (Megasari dan Mutia, 2019). Menurut Walker (2010), penggunaan ruang pendingin cocok untuk penyimpanan cabai karena dapat mempertahankan kesegaran produk untuk waktu yang lebih lama. Kondisi optimum penyimpanan cabai merah segar berada di antara $5^{\circ}-10^{\circ} \mathrm{C}$ dengan kelembaban relatif $95 \%$. Secara fisiologi, cabai merah keriting setelah dipanen tetap melakukan kegiatan metabolisme seperti respirasi dimana laju respirasi ini tergantung dari kondisi lingkungannya. Aktivitas respirasi ini tidak bisa dihentikan tetapi bisa dikurangi dengan cara salah satunya melalui penyimpanan pada suhu rendah yang dikombinasikan dengan pengemasan yang tepat (Lamona et al., 2015). Kemasan sangat erat kaitannya dengan permeabilitas yang merupakan transfer molekul air atau gas melalui kemasan, baik dari dalam kemasan ke lingkungan ataupun sebaliknya (Johnrencius et al., 2017). Semakin kecil nilai permeabilitas suatu kemasan, maka semakin besar kemam-puan kemasan dalam menghalangi keluar masuknya uap air. Selain itu, bulk density dalam kemasan memiliki hubungan yang linier dengan kadar air, semakin tinggi bulk density, kadar air semakin meningkat. Waktu simpan juga mempengaruhi mutu cabai yang meliputi susut bobot, warna, kekerasan, dan kerusakan (Roziqin et al., 2016).

Berdasarkan uraian di atas terkait faktor-faktor yang mempengaruhi mutu cabai selama penyimpanan, maka dilakukan penelitian tentang kombinasi dari faktor-faktor tersebut. Diharapkan dengan adanya kombinasi faktor akan menghasilkan sinergi yang berdampak lebih besar terhadap penjagaan mutu fisik cabai merah selama penyimpanan. Penelitian bertujuan untuk mengetahui kombinasi terbaik dari faktor dan level dari suhu, kemasan, waktu simpan dan bulk density untuk menjaga mutu fisik cabai merah keriting dengan parameter berupa tingkat kerusakan, perubahan warna, peru-bahan berat, dan tingkat kekerasan.

Tahun 2019 diperkirakan konsumsi cabai di tingkat rumah tangga mencapai 562,289 ribu ton sedangkan ditingkat industri hanya sebesar 199,582 ribu ton (Kementerian Perdagangan, 2014). Berdasarkan data tersebut, diketahui bahwa penyuplai pasokan ke rumah tangga seperti ritel modern dan pasar tradisional memiliki peran yang lebih besar dibanding pemasok ke industri. Penyimpanan dalam jumlah besar disertai dengan penjagaan mutu yang cukup ketat seperti rekayasa pengemasan umumnya dilakukan oleh ritel modern. Dengan demikian penelitian ini difokuskan pada penjagaan mutu cabai pada saat penyimpanan sebelum sampai ke tangan konsumen akhir, sehingga ritel modern dianggap paling cocok digunakan sebagai rujukan dalam penelitian karena pada ritel dilakukan rekayasa pengemasan yang ditujukan untuk personal packaging.

\section{METODE}

Bahan yang digunakan, yaitu cabai merah keriting segar varietas OR-42. Cabai yang digunakan adalah cabai dengan persyaratan mutu berdasarkan SNI 4480-2016, dengan kode ukuran 5, yaitu panjang 12-16 $\mathrm{cm}$, penampilan segar, tidak busuk dan tidak 
memiliki memar atau cacat pada cabai tersebut. Cabai berasal dari petani Desa Ngemplak, Sleman yang sudah dikumpulkan di pasar lelang setempat. Kecamatan Ngemplak mempunyai luas panen cabai merah sebesar 212 ha (BPS, 2019). Kemasan yang digunakan dalam penelitian, yaitu PET dengan ketebalan $0,1 \mathrm{~mm}$, ukuran luar $\mathrm{P} \times \mathrm{L} \times \mathrm{T}=19 \mathrm{~cm} \times 13 \mathrm{~cm} \times 4 \mathrm{~cm}$ dan ukuran dalam $16 \mathrm{~cm} \times 10 \mathrm{~cm} \times 4 \mathrm{~cm}$, OPP dengan ketebalam $0,1 \mathrm{~mm}$, ukuran $\mathrm{P} \times \mathrm{L}=27$ $\mathrm{cm} \times 14 \mathrm{~cm}$, alas mika dengan ukuran luar $\mathrm{P} \times$ $\mathrm{L} \times \mathrm{T}=19 \mathrm{~cm} \times 12 \mathrm{~cm} \times 1,5 \mathrm{~cm}$ dan ukuran dalam $16 \mathrm{~cm} \times 10 \mathrm{~cm} \times 1,5 \mathrm{~cm}$, dan wrapping plastic dengan ketebalan $0,1 \mathrm{~mm}$.

Alat yang digunakan dalam penelitian ini, yaitu timbangan analitik (Radwag AS220.R2) untuk uji bobot, chroma meter (Konica Minolta CR-400/410) untuk uji warna, Universal Testing Machine (UTM) (Zwick Z0.5) untuk uji kekerasan, inkubator (Memmert IN-30) untuk menyimpan cabai pada suhu $24^{\circ} \mathrm{C} \pm 2{ }^{\circ} \mathrm{C}$, showcase (Modena Cooler Finestra SC - 1180) untuk menyimpan cabai pada suhu $10^{\circ} \mathrm{C}$, dan cold room untuk menyimpan cabai pada suhu 5 ${ }^{\circ} \mathrm{C}$.

\section{Rancangan Percobaan}

Penelitian ini menggunakan metode Taguchi dengan desain eksperimen yang memungkinkan untuk melaksanakan penelitian dengan melibatkan banyak faktor dengan meminimalkan variasi komponen dan menghasilkan produk yang kokoh terhadap faktor gangguan (Soejanto, 2009). Secara garis besar penelitian dibagi dalam tiga tahapan utama, yaitu desain sistem, desain parameter, dan desain toleransi Taguchi.

\section{Tahapan Penelitian}

Desain Sistem Taguchi

Desain sistem Taguchi dimulai dengan penentuan parameter mutu yang meliputi su- sut bobot, perubahan warna, kekerasan dan persentase kerusakan. Selanjutnya dilakukan pemilihan faktor kontrol yang berpengaruh terhadap parameter mutu yaitu suhu, waktu penyimpanan, kemasan dan bulk density. Terakhir dilakukan penentuan level tiap faktor. Masing-masing faktor tersebut terdiri atas tiga level. Faktor dan level yang digunakan dalam penelitian dapat dilihat pada Tabel 1.

\section{Desain Parameter Taguchi}

Desain parameter Taguchi dilakukan dengan menentukan derajat kebebasan, pemilihan matriks orthogonal, pelaksanaan penelitian dan analisis data. Derajat kebebasan dihitung dengan (banyak faktor) $\mathrm{x}$ (banyak level-1). Pada penelitian ini digunakan empat faktor dan masing-masing terdiri atas tiga level sehingga diperoleh 8 derajat kebebasan. Kemudian dilakukan pemilihan matriks orthogonal standar untuk empat level dan tiga faktor, yaitu $\mathrm{L}_{9}\left(3^{4}\right)$. Matriks orthogonal $\mathrm{L}_{9}\left(3^{4}\right)$ yang menunjukkan kombinasi faktor dan level yang digunakan dalam penelitian ini dapat dilihat pada Tabel 2.

Pelaksanaan penelitian dimulai dengan persiapan sampel yaitu sortasi cabai berdasarkan kriteria warna, ukuran dan tingkat kematangan. Ukuran dipilih yang seragam sesuai SNI 4480:2016, dengan kode ukuran 5, yaitu panjang $12-16 \mathrm{~cm}$, penampilan segar, padat, tidak busuk dan tidak memiliki memar atau cacat pada cabai tersebut. Selanjutnya dilakukan penimbangan menggunakan neraca digital untuk menentukan bulk density atau kepadatan curah yang dihitung dengan rumus pada persamaan berikut.

Kepadatan curah $=\frac{\text { berat produk }(g)}{\text { volume yang ditempati }(c c)}$

Tabel 1. Faktor dan level penelitian

\begin{tabular}{|c|c|c|c|}
\hline \multirow[b]{2}{*}{ Faktor } & \multicolumn{3}{|c|}{ Level } \\
\hline & I & II & III \\
\hline Suhu (A) & $5^{\circ} \mathrm{C}$ & $10^{\circ} \mathrm{C}$ & $22-26^{\circ} \mathrm{C}$ \\
\hline Jenis kemasan (B) & OPP & Wrapping plastic (LDPE) & Mika (PET) \\
\hline Waktu penyimpanan (C) & 2 hari & 4 hari & 6 hari \\
\hline Bulk density (D) & $0,156 \mathrm{~g} / \mathrm{cc}$ & $0,243 \mathrm{~g} / \mathrm{cc}$ & $0,313 \mathrm{~g} / \mathrm{cc}$ \\
\hline
\end{tabular}


Tabel 2. Kombinasi faktor dan level penelitian

\begin{tabular}{ccccc}
\hline Eksperi & \multicolumn{4}{c}{ Level tiap faktor } \\
\cline { 2 - 5 } men & Suhu (A) & Jenis kemasan (B) & Waktu simpan (C) & Bulk density (D) \\
\hline 1 & I & I & I & I \\
2 & I & II & II & II \\
3 & I & III & III & III \\
4 & II & I & II & III \\
5 & II & II & III & I \\
6 & II & III & I & II \\
7 & III & I & III & II \\
8 & III & II & I & III \\
9 & III & III & II & I
\end{tabular}

*I, II, III merupakan level tiap faktor berdasarkan Tabel 1.

Pada perhitungan kepadatan curah digunakan volume yang sama. Volume wadah didapatkan melalui pendekatan hitungan matematis pada volume bagian dalam kemasan mika dengan mengalikan ukuran $\mathrm{P} \times \mathrm{L} \times \mathrm{T}$ untuk ukuran dalamnya, yaitu $16 \mathrm{~cm} \times 10 \mathrm{~cm} \times$ $4 \mathrm{~cm}=640 \mathrm{~cm}^{3}$ atau $640 \mathrm{cc}$. Dua kemasan yang lain disesuaikan dengan penambahan penyangga setinggi $2,5 \mathrm{~cm}$ sehingga memiliki volume yang sama dengan kemasan mika. Untuk memperoleh variasi kepadatan curah digunakan variasi berat yaitu $100 \mathrm{~g}, 150 \mathrm{~g}$, dan $200 \mathrm{~g}$. Berdasarkan perhitungan dengan Persamaan 1 diperoleh variasi kepadatan curah yang digunakan yaitu 0,156 g/cc, 0,243 g/cc, dan 0,313 $\mathrm{g} / \mathrm{cc}$. Cabai yang telah ditimbang kemudian dimasukkan dalam masing-masing kemasan OPP, wapping plastic dan mika (PET).

Cabai yang telah dikemas disimpan pada berbagai suhu. Untuk penyimpanan pada suhu $5{ }^{\circ} \mathrm{C}$, disimpan didalam cold room. Penyimpanan pada suhu $10{ }^{\circ} \mathrm{C}$ di dalam showcase, sedangkan penyimpanan pada suhu ruang $24 \pm$ $2^{\circ} \mathrm{C}$ dilakukan dalam inkubator. Meskipun penyimpanan dilakukan pada alat yang berbeda tergantung suhunya, namun pada masing -masing alat yang digunakan terdapat pengontrol suhu sehingga peneliti dapat mengatur suhu dan meminimalkan pengaruh luar selain suhu yang dapat mengganggu penelitian. Penyimpanan dilakukan selama dua hari, empat hari, dan enam hari. Setelah hari penyimpanan berakhir, dilakukan pengukuran persentase kerusakan, perubahan warna, susut bobot, dan perubahan kekerasan. Pendekatan yang digunakan pada keempat respon parameter adalah smaller the better. Semakin kecil penurunan nilai, semakin baik bagi penjagaan mutu cabai.
Persentase kerusakan, menurut SNI 4480:2016 tentang cabai, dilakukan pengamatan visual untuk menentukan kerusakan. Kerusakan tersebut terdiri atas kerusakan mekanis seperti memar pada permukaan kulit, fisiologis seperti pembusukan, dan kerusakan biologis yang berasal dari hama dan penyakit. Persentase cabai yang mengalami kerusakan dan busuk dapat dihitung menggunakan Persamaan 2.

$\%$ Kerusakan $=\frac{C M R}{C M U} \times 100 \%$

Dengan :

$\mathrm{CMR}=$ jumlah satuan cabai segar dinyatakan mengalami kerusakan.

$\mathrm{CMU}=$ jumlah seluruh cabai yang diuji dalam satu wadah.

Perubahan warna $(\Delta \mathrm{E})$ diukur berdasarkan total perbedaan warna dari sampel sebelum dan setelah diberi perlakuan. Penentuan total warna perbedaan dihitung dengan Persamaan 3.

$\Delta E=\sqrt{\left(\Delta L^{*}\right)^{2}+\left(\Delta a^{*}\right)^{2}+\left(\Delta b^{*}\right)^{2}}$

Dengan :

$\Delta \mathrm{L}^{*}=$ selisih nilai warna $\mathrm{L}^{*}$ sebelum dan setelah perlakuan

$\Delta a^{*}=$ selisih nilai warna $a^{*}$ sebelum dan setelah perlakuan

$\Delta b^{*}=$ selisih nilai warna $b^{*}$ sebelum dan setelah perlakuan

Susut bobot dihitung dengan rumus pada Persamaan 4.

$S b=\frac{W 0}{W n} \times 100 \%$ 
dengan :

$\mathrm{Sb}=$ Susut bobot $(\%)$

W0 $=$ bobot bahan pada hari ke- 0

$\mathrm{Wn}=$ bobot pada hari ke-n

Perubahan kekerasan diukur dengan Universal Testing Machine. Perubahan kekerasan ditentukan dengan menghitung selisih nilai kekerasan sebelum dan setelah perlakuan. Seluruh respon faktor yang muncul kemudian dilakukan analisis data dengan menghitung nilai rata-rata tiap faktor dan perhitungan nilai SNR atau rasio S/N (Signal to Noise). Rasio S/N merupakan logaritma dari rata-rata kuadrat simpangan dari nilai target atau hasil transformasi dari beberapa replikasi data sehingga nilainya mewakili kualitas penyajian variasi. Analisis SNR digunakan untuk memilih faktor mana yang memiliki kontribusi dalam pengurangan variansi suatu respon, serta mengetahui level faktor mana yang memiliki pengaruh pada hasil eksperimen (Telaumbanua et.al, 2013). Karakteristik yang ditentukan dari signal to noise ratio pada penelitian ini adalah smaller the better, yaitu memiliki karakteristik kualitas yang kontinyu dan non negatif, mempunyai nilai dari 0 hingga tak terhingga di mana defect yang diinginkan adalah 0 . Adapun persamaan matematisnya sebagai berikut.

Rasio $\mathrm{S} / \mathrm{N}=-10 \log 10\left[\frac{1}{n} \sum_{i=1}^{n} y_{i}^{2}\right] \ldots \ldots .(5)$

engan :

$\mathrm{n}=$ jumlah pengulangan eksperimen

$\mathrm{y}=$ data pengamatan atau pengukuran ke-I

Kedua, dilakukan penghitungan nilai efek faktor. Hal ini dilakukan untuk menentukan kombinasi terbaik pada peubah respon dan menentukan urutan faktor yang berpengaruh terhadap perubahan respon. Penentuan kombinasi terbaik dilakukan dengan penggabungan efek faktor SNR tiap parameter karena parameter mutu yang digunakan lebih dari satu. Setelah didapatkan hasil dari metode Taguchi untuk keempat parameter, dilakukan penggabungan hasil perhitungan SNR, sehingga dapat diketahui kombinasi level faktor terbaik dengan memilih nilai SNR yang lebih besar dengan beberapa faktor yang digu-nakan.

\section{Desain Toleransi Taguchi}

Tahap terakhir yaitu desain toleransi Taguchi dilakukan eksperimen konformasi, dan perhitungan biaya. Eksperimen konfirmasi dilakukan untuk menguji coba kombinasi faktor dan level terbaik serta membuktikan performansi kombinasi level faktor tersebut. Perhitungan biaya dilakukan dengan membandingkan biaya bahan kemasan per satu unit kemasan.

\section{HASIL DAN PEMBAHASAN}

\section{Analisis Respon Kerusakan}

Karakteristik kerusakan yang diamati dalam penelitian ini dikelompokkan menjadi empat macam, yaitu busuk, berjamur, mengkerut, dan bercak cokelat hingga kehitaman. Kerusakan diamati secara visual kemudian dihitung persentase kerusakannya menggunakan Persamaan 2.

Berdasarkan Tabel 3, diketahui bahwa eksperimen 2 memiliki nilai persentase kerusakan terendah, sedangkan eksperimen 7 memiliki persentase kerusakan tertinggi. Pada eksperimen 2, sampel diberi perlakuan berupa penyimpanan pada suhu $5^{\circ} \mathrm{C}$ selama empat hari dengan muatan bulk density 0,243 $\mathrm{g} / \mathrm{cc}$ menggunakan wrapping plastic, sedangkan pada eksperimen 7 perlakuan yang diberikan berupa penyimpanan pada suhu ruang $\left(22-26{ }^{\circ} \mathrm{C}\right)$ menggunakan kemasan OPP selama enam hari dengan muatan bulk density yang sama. Pada tingkat bulk density yang sama, faktor suhu dapat dibandingkan. Semakin rendah suhu penyimpanan maka kerusakan yang terjadi semakin minimal, demikian pula sebaliknya. Selan-jutnya, data ditransformasikan ke dalam bentuk signal to noise ratio. Nilai respon SNR berkisar antara 27,6189 sampai -9,8530, artinya pada eksperimen kedua yang memiliki nilai SNR terbesar adalah sampel yang memiliki kerusakan paling minimal dibanding yang lainnya.

Pada penelitian ini digunakan karakteristik kualitas smaller the better karena tujuannya meminimalkan penurunan nilai para-meter mutu yang terjadi. Pada hasil perhi-tungan dipilih yang terbesar sebab meskipun berorientasi pada semakin kecil nilainya se-makin baik, namun dalam perhitungan SNR telah ditransformasikan sehingga dapat di-definisikan bahwa semakin besar nilainya maka semakin baik 
Tabel 3. Rata-rata dan SNR respon kerusakan

\begin{tabular}{ccccccc}
\hline Eksperimen & A & B & C & D & Rata-rata (\%) & SNR \\
\hline 1 & I & I & I & I & 5,11 & $-17,1352$ \\
2 & I & II & II & II & $\mathbf{2 , 8 8}$ & $\mathbf{- 9 , 8 5 3 0}$ \\
3 & I & III & III & III & 6,89 & $-16,9117$ \\
4 & II & I & II & III & 4,14 & $-12,3670$ \\
5 & II & II & III & I & 13,75 & $-22,8744$ \\
6 & II & III & I & II & 6,28 & $-17,2444$ \\
7 & III & I & III & II & $\mathbf{2 3 , 3 6}$ & $\mathbf{- 2 7 , 6 1 8 9}$ \\
8 & III & II & I & III & 7,48 & $-18,9752$ \\
9 & III & III & II & I & 17,17 & $-24,7014$ \\
\hline
\end{tabular}

${ }^{*} \mathrm{~A}$ : suhu; B: jenis kemasan; C: waktu simpan; D: bulk density

I, II, III urutan level tiap faktor (A, B, C, D)

Tabel 4. Efek faktor rata-rata untuk respon kerusakan

\begin{tabular}{ccccc}
\hline Level & A & B & C & D \\
\hline I & 4,96 & 10,87 & 6,29 & 12,01 \\
II & 8,06 & 8,04 & 8,06 & 10,84 \\
III & 16,01 & 10,11 & 14,67 & 6,17 \\
Delta & 11,05 & 2,83 & 8,37 & 5,84 \\
\hline
\end{tabular}

*A: suhu; B: jenis kemasan; C: waktu simpan; D: bulk density

Tabel 5. Efek faktor SNR untuk respon kerusakan

\begin{tabular}{ccccc}
\hline Level & A & B & C & D \\
\hline I & $\mathbf{- 1 4 , 6 3}$ & $-19,04$ & $-17,78$ & $-21,57$ \\
II & $-17,50$ & $\mathbf{- 1 7 , 2 3}$ & $\mathbf{- 1 5 , 6 4}$ & $-18,24$ \\
III & $-23,77$ & $-19,62$ & $-22,47$ & $\mathbf{- 1 6 , 0 8}$ \\
Delta & 9,13 & 2,38 & 6,83 & 5,49 \\
Rank & 1 & 4 & 2 & 3 \\
\hline
\end{tabular}

*A: suhu; B: jenis kemasan; C: waktu simpan; D: bulk density

Perhitungan efek faktor dilakukan untuk menentukan kombinasi terbaik pada peubah respon dan menentukan peringkat faktor yang berpengaruh terhadap peubah respon. Efek faktor dari masing-masing level tiap faktor diperoleh dengan menghitung nilai rata-rata mutu dari konsep faktor kontrol mutu yang yang didalamnya terdapat kombinasi level tersebut. Nilai yang diperoleh kemudian dilakukan pengurangan dari level dengan nilai tertinggi dikurangi nilai terendah untuk tiaptiap faktor untuk menghasilkan nilai efek faktor rata-rata dari faktor level tersebut. Nilai yang paling besar menandakan pengaruh yang lebih besar dari faktor tersebut. Efek faktor ratarata dan SNR dapat dilihat pada Tabel 4 dan Tabel 5.

Berdasarkan Tabel 4 dan 5, diketahui bahwa urutan signifikansi faktor dan level berdasarkan SNR respon kerusakan dari urutan 1 sampai 4 adalah faktor suhu, waktu simpan, bulk density, dan faktor jenis kemasan. Faktor yang paling berpengaruh terhadap respon kerusa-kan berdasarkan perhitungan efek faktor ada-lah faktor A, yaitu suhu. Eksperimen dengan faktor A level I (suhu $5^{\circ} \mathrm{C}$ ) akan menghasilkan nilai rata-rata kerusakan yang rendah. Penyim-panan pada suhu rendah dapat menjaga mutu produk 
lebih baik karena semakin rendah suhu, tingkat perkembangan mikroorganisme semakin berkurang. Mikroorganisme berkembang lebih baik pada suhu ruang sehingga tingkat kerusakan semakin tinggi (Roziqin et al., 2016). Mikroba yang berasosiasi dengan tingkat kesegaran cabai yaitu bakteri Bacillus, sp dan jamur Rhizopus, sp serta jamur Aspergillus, sp (Hongi et al., 2015). Adapun kombinasi level faktor terbaik, yaitu faktor suhu $5^{\circ} \mathrm{C}$, kemasan wrapping plastic, waktu simpan empat hari, dan bulk density $0,313 \mathrm{~g} / \mathrm{cc}$.

\section{Analisis Respon Perubahan Warna}

Warna pada cabai dapat menandakan tingkat kematangan dan kesegaran. Perubahan warna dapat diindikasikan sebagai penurunan mutu. Pada penelitian ini diukur perubahan war-na yang terjadi dan dihitung total peru- bahan warnanya dengan Persamaan 3. Eksperimen dengan perubahan warna paling kecil adalah eksperimen paling baik karena berarti produk hanya mengalami sedikit perubahan warna. Hasil per-hitungan total perubahan warna dapat dilihat pada Tabel 6 .

Berdasarkan Tabel 6, diketahui bahwa eksperimen 1 memiliki nilai $\Delta \mathrm{E}$ terendah sedangkan eksperimen 9 memiliki nilai $\Delta \mathrm{E}$ tertinggi. Eksperimen 1 disimpan pada suhu $5^{\circ} \mathrm{C}$, selama dua hari dengan muatan bulk density 0,156 g/cc menggunakan kemasan OPP. Perlakuan pada eksperimen 9 antara lain disimpan pada suhu ruang $\left(22-26^{\circ} \mathrm{C}\right)$, selama empat hari, menggunakan kemasan mika (PET). Nilai respon SNR berdasarkan perhitungan berkisar antara 12,2629 sampai -12,6337, yang berarti perubahan warna paling sedikit atau mutu yang paling baik adalah eksperimen 1 .

Tabel 6. Rata-rata untuk respon perubahan warna

\begin{tabular}{ccccccc}
\hline Eksperimen & A & B & C & D & Rata-Rata $\Delta$ E & SNR \\
\hline 1 & I & I & I & I & $\mathbf{4 , 1 0}$ & $\mathbf{- 1 2 , 6 3 3 7}$ \\
2 & I & II & II & II & 6,82 & $-16,9959$ \\
3 & I & III & III & III & 6,70 & $-16,6063$ \\
4 & II & I & II & III & 8,23 & $-18,3456$ \\
5 & II & II & III & I & 7,79 & $-17,8303$ \\
6 & II & III & I & II & 5,60 & $-15,2980$ \\
7 & III & I & III & II & 9,80 & $-19,8475$ \\
8 & III & II & I & III & 11,96 & $\mathbf{- 2 1 , 5 9 2 5}$ \\
9 & III & III & II & I & $\mathbf{1 2 , 9 2}$ & $\mathbf{- 2 2 , 2 6 2 9}$ \\
\hline
\end{tabular}

*A: suhu; B: jenis kemasan; C: waktu simpan; D: bulk density. I, II, III urutan level tiap faktor (A, B, C, D)

Tabel 7. Efek faktor rata-rata untuk respon perubahan warna

\begin{tabular}{ccccc}
\hline Level & A & B & C & D \\
\hline I & 5,87 & 7,38 & 7,22 & 8,27 \\
II & 7,21 & 8,86 & 9,33 & 7,41 \\
III & 11,56 & 8,41 & 8,10 & 8,97 \\
Delta & 5,69 & 1,48 & 2,11 & 1,56 \\
\hline
\end{tabular}

*A: suhu; B: jenis kemasan; C: waktu simpan; D: bulk density

Tabel 8. Efek faktor SNR untuk respon perubahan warna

\begin{tabular}{ccccc}
\hline Level & A & B & C & D \\
\hline I & $\mathbf{- 1 5 , 4 1}$ & $\mathbf{- 1 6 , 9 4}$ & $\mathbf{- 1 6 , 5 1}$ & $-\mathbf{1 7 , 5 8}$ \\
II & $-17,16$ & $-18,81$ & $-19,20$ & $\mathbf{- 1 7 , 3 8}$ \\
III & $-21,23$ & $-18,06$ & $-18,09$ & $-18,85$ \\
Delta & 5,82 & 1,86 & 2,69 & 1,47 \\
Rank & 1 & 3 & 2 & 4 \\
\hline
\end{tabular}

*A: suhu; B: jenis kemasan; C: waktu simpan; D: bulk density 
Berdasarkan perhitungan efek faktor SNR pada Tabel 8, faktor yang paling berpengaruh terhadap respon perubahan warna adalah faktor A (suhu) dengan level I. Eksperimen dengan faktor A level I (suhu $5^{\circ} \mathrm{C}$ ) akan menghasilkan nilai rata-rata perubahan warna yang paling rendah, seiring meningkatnya suhu penyimpanan maka perubahan warna yang terjadi semakin besar.

Dengan demikian, semakin rendah suhu penyimpanan maka penurubahan warna yang terjadi semakin kecil. Secara fisiologi, setelah dipanen cabai merah keriting tetap melakukan kegiatan metabolisme dan degradasi karotenoid yang merupakan pigmen pada cabai. Degradasi karotenoid dapat menurunkan warna merah cerah pada cabai sehingga semakin gelap. Karotenoid bertanggung jawab atas berbagai warna buah dalam varietas cabai yang berbeda, dari putih menjadi merah tua (Puglise et al., 2014). Hal ini berhubungan langsung antara derajat kemerahan cabai dengan kadar B-karoten, semakin merah cabai semakin tinggi kadar B-karoten dan ini dipengaruhi antara lain oleh tingkat kematangan cabai (Octaviani et al., 2014). Aktivitas ini tidak bisa dihentikan tetapi bisa dikurangi dengan cara salah satunya melalui penyimpanan pada suhu rendah (Lamona et al., 2015).

Penggunaan kemasan OPP menghasilkan perubahan warna paling sedikit. hal ini karena OPP memiliki performansi paling bagus dalam menahan uap air dengan nilai permeabilitas 3,9-6,2 g/ $\mathrm{m}^{2}$ hari. Kombinasi dari suhu rendah dan kemasan ini dapat mengurangi terjadinya penguapan air sehingga tingkat kecerahannya lebih tinggi dari cabai yang disimpan pada suhu tinggi dan kemasan lainnya (Lamona et al., 2015). Adapun kombinasi level faktor yang terbaik yang dapat diterapkan untuk memi-nimalkan respon perubahan warna yaitu suhu $5^{\circ} \mathrm{C}$, kemasan OPP, waktu simpan 2 hari de-ngan muatan bulk density $0,243 \mathrm{~g} / \mathrm{cc}$.

\section{Analisis Respon Perubahan Bobot}

Kandungan air pada cabai segar yang baru dipanen sekitar $77,74 \%$ menyebabkan produk harus segera diberi penanganan agar tidak terjadi kebusukan atau mengalami kekeringan akibat tingginya aktivitas respirasi dan transpirasi setelah cabai dipanen (Lamona et al., 2015). Apabila terlalu banyak air yang keluar maka cabai akan mengalami pengurangan bobot. Perhitungan perubahan bobot dilakukan dengan Persamaan 4.

Berdasarkan Tabel 9, diketahui bahwa eksperimen 1 memiliki nilai rata-rata penurunan bobot terendah sedangkan eksperimen 9 memiliki nilai selisih penurunan tertinggi. Perlakuan pada eksperimen 1 yaitu disimpan pada suhu $5^{\circ} \mathrm{C}$ selama dua hari dengan muatan bulk density $0,156 \mathrm{~g} / \mathrm{cc}$ menggunakan plastik OPP.

Pada eksperimen 9 perlakuannya antara lain disimpan pada suhu $\left(22-26^{\circ} \mathrm{C}\right)$, selama empat hari, menggunakan kemasan mika (PET) dengan muatan bulk density 0,156 g/cc. Pada tingkat bulk density yang sama, faktor suhu, jenis plastik, dan lama waktu simpan dapat dibandingkan. Semakin rendah suhu, semakin cepat waktu simpan, dan semakin rendah permeabilitas kemasan, susut bobot semakin kecil.

Tabel 9. Rata-rata untuk respon perubahan bobot

\begin{tabular}{ccccccc}
\hline Eksperimen & A & B & C & D & $\begin{array}{c}\text { Rata-Rata } \\
\text { Penurunan Bobot } \\
\text { (gram) }\end{array}$ & SNR \\
\hline 1 & & & & & $\mathbf{0 , 0 1}$ & $\mathbf{2 6 , 5 7 5 8}$ \\
2 & I & I & I & I & 0,45 & 6,8235 \\
3 & I & II & II & II & 8,83 & $-18,9841$ \\
4 & I & III & III & III & 0,74 & 0,9248 \\
5 & II & I & II & III & II & $-6,4772$ \\
6 & II & II & III & I & 2,03 & $-15,4560$ \\
7 & II & III & I & II & 5,88 & $-4,8286$ \\
8 & III & I & III & II & 1,65 & $-12,7250$ \\
9 & III & II & I & III & 4,33 & $\mathbf{- 2 2 , 8 8 9 3}$ \\
\hline
\end{tabular}

*A: suhu; B: jenis kemasan; C: waktu simpan; D: bulk density. I, II, III urutan level tiap faktor (A, B, C, D) 
Karakteristik perhitungan SNR yang dituju adalah smaller the better yakni semakin kecil nilainya semakin baik mutunya, atau merupakan karakteristik mutu dengan batas nilai nol dan non negatif. Semakin kecil nilai atau mendekati nol adalah yang diinginkan. Walaupun karak-teristik mutu semakin kecil semakin baik, tetapi nilai SNR selalu dapat ditransformasikan karak-teristik mutu menjadi karakteristik semakin besar semakin baik (Soejanto, 2009). Nilai respon SNR berdasarkan perhitungan berkisar antara $-22,8893$ sampai 26,5758 , yang berarti eksperimen dengan nilai SNR terbesar memiliki kondisi terbaik atau respon penurunan bobot terkecil.

Selanjutnya, dicari efek faktor untuk ratarata dan SNR respon perubahan bobot guna mencari urutan signifikansi faktor dan level yang mempengaruhi perubahan bobot. Berdasarkan perhitungan efek faktor SNR pada Tabel 11, faktor yang paling berpengaruh terhadap respon susut bobot adalah faktor B (kemasan) dengan level I. Eksperimen dengan faktor B level I (kemasan OPP) akan menghasilkan nilai penurunan bobot yang paling rendah dibanding level faktor yang lain. Hal ini sesuai dengan teori, bahwa kemasan atau plastik yang memiliki performansi paling ba-gus dalam menahan uap air adalah OPP dengan nilai permeabilitas 3,9-6,2 $\mathrm{g} / \mathrm{m}^{2}$ hari. Permeabilitas merupakan transfer molekul air atau gas melalui kemasan, baik dari dalam kemasan ke lingkungan ataupun sebaliknya (Johnrencius et al., 2017). Semakin kecil nilai permeabilitas suatu kemasan, maka semakin besar kemampuan kemasan dalam menghalangi uap air lebih baik. Artinya, proses terjadinya susut bobot dapat dihambat. Adapun kombinasi level faktor yang terbaik yang dapat diterapkan untuk meminimalkan respon penurunan bobot yaitu suhu 5 ${ }^{\circ} \mathrm{C}$, kemasan OPP, waktu simpan 2 hari dengan muatan bulk density 0,156 g/cc.

\section{Analisis Respon Perubahan Kekerasan}

Nilai kekerasan yang tinggi mengindikasikan terjadinya kekeringan pada cabai. Hal ini disebabkan oleh besarnya nilai kehilangan air dari cabai yang mengakibatkan cabai menjadi layu dan keriput sehingga teksturnya menjadi lebih keras. Kekerasan cabai diukur dengan Universal Testing Machine, sebelum dan setelah diberi perlakuan yang kemudian dihitung selisihnya. Perubahan kekerasan pada sampel cabai tiap eksperimen dapat dilihat pada Tabel 12.

Tabel 10. Efek faktor rata-rata untuk respon perubahan bobot

\begin{tabular}{ccccc}
\hline Level & A & B & C & D \\
\hline I & 3,10 & 0,80 & 3,40 & 5,32 \\
II & 2,88 & 2,27 & 5,04 & 2,66 \\
III & 6,63 & 9,54 & 4,17 & 4,63 \\
Delta & 3,75 & 8,74 & 1,63 & 2,66 \\
\hline
\end{tabular}

*A: suhu; B: jenis kemasan; C: waktu simpan; D: bulk density

Tabel 11. Efek faktor SNR untuk respon susut bobot

\begin{tabular}{ccccc}
\hline Level & A & B & C & D \\
\hline 1 & $\mathbf{4 , 8 1}$ & $\mathbf{7 , 5 6}$ & $-\mathbf{0 , 5 4}$ & $\mathbf{- 0 , 9 3}$ \\
2 & $-7,00$ & $-4,13$ & $-5,05$ & $-4,49$ \\
3 & $-13,48$ & $-19,11$ & $-10,1$ & $-10,26$ \\
Delta & 18,29 & 26,67 & 9,56 & 9,33 \\
Rank & 2 & 1 & 3 & 4 \\
\hline
\end{tabular}

*A: suhu; B: jenis kemasan; C: waktu simpan; D: bulk density 
Tabel 12. Rata-Rata untuk respon perubahan kekerasan

\begin{tabular}{ccccccc}
\hline Eksperimen & A & B & C & D & $\begin{array}{c}\text { Rata-rata Perubahan } \\
\text { Kekerasan (gf) }\end{array}$ & SNR \\
\hline $\mathbf{1}$ & I & I & I & I & 4,05 & $-12,1752$ \\
$\mathbf{2}$ & I & II & II & II & 4,32 & $-12,7161$ \\
$\mathbf{3}$ & I & III & III & III & 4,36 & $-12,8086$ \\
$\mathbf{4}$ & II & I & II & III & 4,56 & $-13,1884$ \\
$\mathbf{5}$ & II & II & III & I & $\mathbf{4 , 6 0}$ & $\mathbf{- 1 3 , 2 5 9 5}$ \\
$\mathbf{6}$ & II & III & I & II & 3,19 & $\mathbf{- 1 0 , 1 0 6 8}$ \\
$\mathbf{7}$ & III & I & III & II & 3,70 & $-11,4560$ \\
$\mathbf{8}$ & III & II & I & III & 3,65 & $-11,2893$ \\
$\mathbf{9}$ & III & III & II & I & 4,41 & $-13,0067$ \\
\hline
\end{tabular}

*A: suhu; B: jenis kemasan; C: waktu simpan; D: bulk density. I, II, III urutan level tiap faktor (A, B, C, D)

Berdasarkan Tabel 12, diketahui bahwa eksperimen 6 memiliki nilai selisih terendah sedangkan eksperimen 5 memiliki nilai selisih tertinggi. Pada eksperimen 6 perlakuan yang diberikan adalah penyimpanan pada suhu 10 ${ }^{\circ} \mathrm{C}$ selama dua hari dengan muatan bulk density $0,243 \mathrm{~g} / \mathrm{cc}$ menggunakan kemasan mika (PET). Perlakuan pada eksperimen 5 antara lain, disimpan pada selama enam hari dengan muatan bulk density 0,156 g/cc, dengan wrapping plastic, dan suhu sama seperti eksperimen 5 yaitu 10 ${ }^{\circ} \mathrm{C}$. Pada penyimpanan suhu yang sama, faktor lama waktu simpan dapat dibandingkan. Semakin cepat waktu simpan penurunan kekerasan yang terjadi semakin kecil, demikian pula sebaliknya. Data ditransformasikan kedalam bentuk signal to noise ratio. Nilai respon SNR berkisar antara -13,2595 sampai -10,1068. Sesuai dengan karakteristik smaller the better, apabila hasil perhitungan SNR seluruhnya negatif maka nilai yang terbesar menunjukkan kondisi yang terbaik.

Selanjutnya, dicari efek faktor untuk rata-rata dan SNR respon perubahan kekerasan guna mencari urutan signifikansi faktor dan level yang mempengaruhi perubahan kekerasan. Delta atau selisih nilai hasil perhitungan menunjukkan tingkat signifikansi faktor yang berpengaruh.

Tabel 13. Efek faktor rata-rata untuk respon perubahan kekerasan

\begin{tabular}{ccccc}
\hline Level & A & B & C & D \\
\hline I & 4,24 & 4,11 & 3,63 & 4,35 \\
II & 4,12 & 4,19 & 4,43 & 3,74 \\
III & 3,92 & 3,99 & 4,22 & 4,19 \\
Delta & 0,32 & 0,20 & 0,80 & 0,61 \\
\hline
\end{tabular}

*A: suhu; B: jenis kemasan; C: waktu simpan; D: bulk density

Tabel 14. Efek Faktor SNR untuk Respon Perubahan Kekerasan

\begin{tabular}{ccccc}
\hline Level & A & B & C & D \\
\hline I & $-12,57$ & $-12,27$ & $\mathbf{- 1 1 , 1 9}$ & $-12,81$ \\
II & $-12,18$ & $-12,42$ & $-12,97$ & $\mathbf{- 1 1 , 4 3}$ \\
III & $\mathbf{- 1 1 , 9 2}$ & $\mathbf{- 1 1 , 9 7}$ & $-12,51$ & $-12,43$ \\
Delta & 0,65 & 0,45 & 1,78 & 1,39 \\
Rank & 3 & 4 & 1 & 2 \\
\hline
\end{tabular}

*A: suhu; B: jenis kemasan; C: waktu simpan; D: bulk density 
Berdasarkan Tabel 14, diketahui bahwa urutan signifikansi faktor dan level berdasarkan efek faktor SNR respon kekerasan dari urutan 1 sampai 4 adalah faktor waktu simpan, bulk density, faktor suhu, dan faktor kemasan. Faktor yang paling berpengaruh terhadap respon perubahan kekerasan adalah faktor C (kemasan) dengan level I. Eksperimen dengan faktor C level I (waktu simpan dua hari) akan menghasilkan peningkatan nilai kekerasan yang paling rendah. Adapun kombinasi level faktor yang terbaik yang dapat diterapkan untuk meminimalkan respon perubahan kekerasan yaitu suhu ruang $\left(22-26^{\circ} \mathrm{C}\right)$, dengan kemasan mika (PET), waktu simpan 2 hari, dan muatan bulk density 0,156 g/cc.

Pada faktor suhu simpan, suhu ruang yaitu $22-26^{\circ} \mathrm{C}$ bukanlah suhu terendah namun memberikan hasil terbaik untuk menjaga mutu cabai dari perubahan kekerasan. Secara fisiologi, setelah dipanen cabai merah keriting tetap melakukan kegiatan metabolisme. Penyimpanan dalam suhu rendah dapat menghambat proses metabolisme seperti respirasi dan transpirasi yang menyebabkan kehilangan air pada cabai dalam jumlah tinggi. Hal tersebut dapat meminimalisir terjadinya kekerasan.

\section{Kombinasi Level Terbaik Berdasarkan Efek Faktor SNR}

Tabel 15 menunjukkan rancangan usulan untuk kombinasi level faktor yang terbaik dari faktor yang berpengaruh terhadap kualitas cabai merah keriting segar. Kombinasi level faktor terbaik yang diperoleh, yaitu faktor suhu level I $\left(5^{\circ} \mathrm{C}\right)$, faktor kemasan level I (OPP), faktor waktu simpan level I (dua hari), dan faktor bulk density level II (0,243 g/cc).

Pada penerapannya, kondisi penyimpanan seperti ini hanya dapat dilakukan oleh ritel modern tipe hypermart, sebab membutuhkan biaya penanganan yang tinggi dalam penyimpanan suhu rendah $5{ }^{\circ} \mathrm{C}$ sehingga berdampak pada mahalnya harga produk yang dijual. Nilai belanja konsumen di ritel semacam hypermart lebih dari $\mathrm{Rp}$ 75.000,00/kunjungan sehingga dianggap lebih sesuai menyerap produk dengan harga tinggi (Sujana, 2012). Pada faktor penyimpanan dengan umur simpan dua hari dimaksudkan untuk memberikan rekomendasi pada masa penjualan produk. Hal ini hanya dapat berlaku bila cabai yang telah dipanen langsung dikemas dan didistribusikan ke hypermart untuk dijual atau dilakukan penjualan fresh product. Apabila hendak dilakukan penanganan produk yang memerlukan waktu lebih lama, maka faktor dan level terbaik selain waktu simpan dapat digunakan sebagai rekomendasi.

Secara umum, setelah pemanenan produk hortikultura proses respirasi dan trasnpirasi masih terus berlangsung dan dapat menyebabkan penurunan mutu dan mempersingkat masa simpan. Hal tersebut dapat diatasi dengan penyimpanan produk yang tepat seperti pengemasan dan penjagaan suhu. Pengemasan dilakukan dengan mempertimbangkan faktor yang penting seperti sifat permeabilitas bahan pengemas, sedangkan penjagaan suhu agar tetap stabil dilakukan dengan cara penyimpanan pada suhu rendah. Suhu rendah mampu mempertahankan mutu buah yang memiliki kaitan erat dengan laju respirasi pada suatu produk. Batas kritis penyimpanan dingin yaitu pada suhu $10^{\circ} \mathrm{C}$, sedangkan suhu lebih rendah akan mempercepat terjadinya cilling injury (Sumiasih et. al., 2016).

Tabel 15. Kombinasi level terbaik berdasarkan efek faktor SNR

\begin{tabular}{cccccc}
\hline Faktor & \multicolumn{5}{c}{ Perubahan } \\
\cline { 2 - 5 } & P1 & P2 & P3 & P4 & Level Terbaik \\
\hline A & I & I & I & III & I \\
B & II & I & I & III & I \\
C & II & I & I & I & I \\
D & III & II & I & II & II \\
\hline
\end{tabular}

*P1= persentase kerusakan, $\mathrm{P} 2=$ perubahan warna, $\mathrm{P} 3=$ susut bobot, $\mathrm{P} 4=$ perubahan kekerasan.

A: suhu; B: jenis kemasan; C: waktu simpan; D: bulk density 
Tabel 16. Perbandingan hasil eksperimen sebelum perbaikan dan eksperimen konfirmasi

\begin{tabular}{lll}
\hline \multicolumn{1}{c}{ Parameter } & \multicolumn{1}{c}{$\begin{array}{c}\text { Eksperimen Sebelum } \\
\text { Perbaikan }\end{array}$} & \multicolumn{1}{c}{ Eksperimen Konfirmasi } \\
\hline Persentase Kerusakan & $2,88-17,17 \%$ & $0 \%$ \\
Perubahan Warna & $16,93-84,19$ & 5,54 \\
Perubahan Bobot & $0,45-13,92 \mathrm{~g}$ & $0,01 \mathrm{~g}$ \\
Perubahan Kekerasan & $3,19-4,4 \mathrm{gf}$ & $0,74 \mathrm{gf}$ \\
\hline
\end{tabular}

Tabel 17. Perubahan biaya dengan penggantian kemasan OPP (harga OPP Rp 190,00)

\begin{tabular}{lccl}
\hline $\begin{array}{c}\text { Jenis Kemasan yang } \\
\text { Diganti }\end{array}$ & $\begin{array}{c}\text { Harga } \\
\text { (Rupiah) }\end{array}$ & $\begin{array}{c}\text { Selisih Harga Kemasan } \\
\text { (Rupiah) }\end{array}$ & Perubahan Biaya \\
\hline PET & 400 & 210 & Berkurang $52,5 \%$ \\
LDPE & 122 & -68 & Bertambah $55,73 \%$ \\
\hline
\end{tabular}

\section{Eksperimen Konfirmasi}

Berdasarkan hasil eksperimen pada Tabel 16., diketahui bahwa hasil eksperimen konfirmasi menunjukkan hasil pengukuran parameter mutu yang lebih baik. Pada keempat parameter mutu, semakin kecil nilai-nya maka semakin baik. Pada parameter presentase kerusakan, eksperimen konfirmasi tidak mengalami kerusakan sama sekali. Pada parameter perubahan bobot, semakin kecil berkurangnya bobot, semakin baik. Pada hasil eksperimen konfirmasi hanya terdapat penurunan bobot sebesar 0,01 g. Sedangkan pada eksperimen sebelum perbaikan terdapat penurunan bobot lebih besar, yaitu 0,45-13,92 g. Pada parameter perubahan warna, semakin kecil nilainya berarti semakin sedikit perubahan warna yang terjadi dari warna awal. Nilai $\Delta \mathrm{E}$ pada eksperimen konfirmasi sebesar 5,54. Sedangkan pada eksperimen sebelum perbaikan nilai $\Delta \mathrm{E}$ sebesar 16,93-84,19. Pada parameter perubahan kekerasan, semakin kecil nilainya artinya semakin kecil perubahan kekerasan tekstur cabai. Pada parameter perubahaan kekerasan, nilai perubahan kekerasannya sebesar 0,74 gf. Sedangkan pada ek-sperimen sebelum perbaikan nilainya sebesar 3,19-4,4 gf.

Pengemasan harus memperhatikan jenis kemasan dan kondisi produknya. Kombinasi jenis bahan pengemas dan tingkat kema-tangan cabai akan mempengaruhi kualitas dan ketahanan simpan. Penelitian Rochayat dan Munika (2015), menunjukkan bahan penge-mas clear polyethelen atau plastic wrap dengan tingkat kematangan buah cabai 50-60\% me-rupakan kombinasi pengemasan yang paling baik dibanding menggunakan kemasan kotak dus karton yang dikombinasikan dengan kematangan buah cabai $60-70 \%$. Penelitian lain oleh
Musaddad et. al. (2019) menunjukkan pengemasan dengan styrofoam yang dibungkus plastik stretch film kapasitas $250 \mathrm{~g}$ memberikan efek positif pada kesegaran semua jenis cabai yang disimpan di suhu dingin $\left(10 \pm 1^{\circ} \mathrm{C}\right)$ dibanding dengan pengemasan lain seperti styrofoam tanpa pembungkus (terbuka) dan styrofoam dibungkus plastik PE 0,3 $\mathrm{mm}$ berperforasi.

\section{Biaya Penjagaan Mutu}

Analisis biaya penjagaan mutu dimaksudkan agar dapat membandingkan biaya ba-han kemasan per satu unit kemasan. Kemasan dipilih karena paling mudah dilakukan perhi-tungan biaya dibanding 3 faktor lainnya. Biaya penjagaan mutu seperti di tampilkan pada Tabel 17.

Berdasarkan Tabel 17, dari segi biaya dapat diketahui penggantian plastik PET dengan OPP dapat menghemat biaya 52,5\%. Se-dangkan penggantian plastik LDPE dengan OPP dapat menimbulkan tambahan biaya $55,73 \%$.

\section{SIMPULAN}

Berdasarkan penggabungan efek faktor SNR, diperoleh kombinasi faktor dan level terbaik untuk menajaga mutu cabai merah keriting adalah faktor suhu pada nilai $5{ }^{\circ} \mathrm{C}$, faktor kemasan digunakan plastik jenis OPP, faktor waktu simpan pada dua hari, dan faktor bulk density pada nilai 0,243 g/cc. Pada kondisi tersebut dihasilkan presentase keru-sakan $0 \%$, perubahan bobot $0,01 \mathrm{~g}$, perubahan warna senilai 5,54, dan perubahan kekerasan 0,74 gf. 


\section{DAFTAR PUSTAKA}

BPS. 2019. Kabupaten Sleman dalam Angka 2019. Badan Pusat Statistik Kabupaten Sleman, Sleman. https://slemankab.bps. go.id/publication/2019/08/16/c400805c 8dee98a3d701ea33/kabupaten-slemandalam-angka-2019.html

David, H, J., Kilmanun, C, J. 2016. Penanganan pasca panen penyimpanan untuk komoditas hortikultura. Prosiding Seminar Nasional Inovasi Teknologi Pertanian, Balai Pengkajian Teknologi Pertanian. Banjarbaru, pp. 1015-1026.

Hongi, H, N, A., Ijong, F, G., Mamuaja, C, F. 2015. Komposisi mikroba berasosiasi dengan tingkat kepedasan dan kesegaran cabe rawit (Capsicum frutescens) selama penyimpanan pada suhu ruang. Jurnal Ilmu dan Teknologi Pangan. 3(1), 35-43. https:// ejournal.unsrat.ac.id/index,php /itp/article/view/13357/12942

Johnrencius, M., Herawati, N., Johan, V,-S. 2017. Pengaruh penggunaan kemasan terhadap mutu kukis sukun. JURNAL JOM FAPERTA UR. 4(1), 1-15. https://jom.unri.ac.id/index.php/JOMF APERTA/article/view/16956/16372

Kementerian Perdagangan. 2014. Analisis Outlook Pangan 2015-2019. Pusat Kebijakan Pangan Dalam Negeri Badan Pengkajian dan Pengembangan Kebijakan Perdagangan, Kementerian Perdagangan 2014. http:// bppp.kemendag.go.id/ media_content/2017/08/Analisis_Outlo ok_Pangan_2015-2019.pdf

Kementerian Pertanian. 2018. Outlook Cabai: Komoditas Ekspor Subsektor Hortikultura. Pusat Data dan Sistem Informasi Pertanian, Sekretariat Jenderal Kementerian Pertanian 2018, No. 1907-1507.

Lamona, A., Aris, Y., Sutrisno. 2015. Pengaruh jenis kemasan dan penyimpanan suhu rendah terhadap perubahan kua-litas cabai merah keriting segar. Jurnal Keteknikan Pertanian. 3(2), 145-152. http://jour nal.ipb.ac.id/index.php/jtep/article/vie $\mathrm{w} / 10843 / 8366$

Megasari, R., Mutia, A, K. 2019. Pengaruh lapisan edible coating kitosan pada cabai keriting (Capsicum annum L) dengan penyimpanan suhu rendah. Journal of Agritec Science. 3(2), 118-127. https:/ / doi. org/10.30869/jasc.v3i2.389

Musaddad, D., Rahayu, S, T., Levianny, P, S. 2019. Perubahan atribut mutu dan umur simpan beberapa jenis cabai pada berbagai kemasan dan suhu penyimpanan. Jurnal Hort. 29(1), 111-118. http:// ejurnal.litbang.pertanian.go.id/in dex.php/jhort/article/view/8927

Octaviani, T., Guntarti, -A., Susanti, -H. 2014. Penetapan kadar B-Karoten pada beberapa jenis cabe (Genus Capsicum) dengan metode spektrofotometri tam-pak. Journal of Phamarciana. 4(4), 101-109. https: //doi.org/10.12928/pharmaciana.v4i2

Pugliese, A., O'callaghan, Y., Tundis, R., Galvin, K., Menichini, F., O'brien, N., Loizzo, M, R. 2014. In vitro investigation of the bioaccessibility of carotenoids from raw, frozen and boiled red chili peppers (Capsicum annuum). European Journal of Nutrition. 53(2), 501-510. https://doi.org/10.1007/s00394-013-5551

Rockhayat, Y., Munika, V, R. 2015. Respon kualitas dan ketahanan simpan buah cabai merah (Capsicum annuum L.) dengan penggunaan jenis bahan pengemas dan tingkat kematangan buah. Jurnal Kultivasi. 14(1), 65-71. https://doi.org/ 10.24198/kultivasi.v14i1.12093

Roziqin., M, K., Purwanto, Y, A. 2016. Respon kualitas penyimpanan cabai merah keriting (Capsicum annuum L.) pada berbagai suhu penyimpanaan. https:// repository.ipb.ac.id/handle/123456789/ 85744

Soejanto, I. 2009. Desain Eksperimen Dengan Metode Taguchi. Graha Ilmu, Yogya-karta.

Sujana, A. 2012. Manajemen Minimarket. Raih Asa Sukses, Jakarta.

Sumiasih, I, H., Octaviani, L., Lestari, D, I., Yunita, E, R. 2016. Studi perubahan kualitas pascapanen buah belimbing dengan beberapa pengemasan dan suhu simpan. Agrin. 20(2), 115-124. https:// doi.org/10.20884/1.agrin.2016.20.2.319 
Jurnal Teknologi Pertanian Vol. 21 No. 2 [Agustus 2020] 80-93 Analisis Pengaruh Suhu dan Kemasan pada Perlakuan Penyimpanan [Khuriyati dkk]

Telaumbanua, A., Siregar, K, Sinaga, T, S. 2013. Analisis pengendalian kualitas dengan pendekatan metode taguchi pada PT Asahan Crumb Rubber. e-J. Tek Ind FT USU. 3(5), 1-7. https://jurnal.usu.ac.id/ /index.php/jti/article/view/6137/pdf

Walker, S. 2010. Postharvest Handling of Fresh Chiles. New Mexico State University. Mexico. 